\title{
What Is Exactly the Scope of Nuclear Chemistry and Its Educational Position between Other Chemistry Branches*
}

\author{
Turan Ünak ${ }^{1,2}$ \\ ${ }^{1}$ Nuclear Chemistry, Ege University, Izmir, Turkey \\ ÜNAK'lar Company, Izmir, Turkey \\ Email: turan@unak-nukleer.com
}

How to cite this paper: Ünak, T. (2017) What Is Exactly the Scope of Nuclear Chemistry and Its Educational Position between Other Chemistry Branches. Advances in Chemical Engineering and Science, 7, 60-75. http://dx.doi.org/10.4236/aces.2017.71006

Received: November 15, 2016

Accepted: January 6, 2017

Published: January 9, 2017

Copyright $\odot 2017$ by author and Scientific Research Publishing Inc. This work is licensed under the Creative Commons Attribution International License (CC BY 4.0).

http://creativecommons.org/licenses/by/4.0/ cc) (i)

Open Access

\begin{abstract}
The undergraduate chemistry programs of different universities across the world show clearly that nuclear chemistry education doesn't have a permanent status in chemistry curricula like classical sub-branches of chemistry which means like organic, inorganic, analytical, physical, and biochemistry. Before starting the evaluation of the status of nuclear chemistry education, first of all, nuclear chemistry should correctly be defined and its position in chemistry education programs should correctly be determined. In addition, a confusion of terminology or at least, a terminological turbulence exists in this branch of chemistry about the use of terms such as nuclear chemistry, radiochemistry, nuclear and radiochemistry. Also, the scopes of the expressions used in this field such as radiochemistry, radiation chemistry, radiopharmaceutical chemistry, etc. should be exactly defined and the realtions between them should be clearly understood. Breifly, nuclear chemistry may be difined as a large umbrella which covers all chemical studies related to radioactive materials and nuclear radiation including the fine sub-branches such as radiochemistry, radiation chemistry, radioanalytical chemistry, radiopharmaceutical chemistry, environmental radiochemistry. If these are not done, the educational problems in nuclear chemistry could not be correctly investigated and the remedies could not be correctly determined.
\end{abstract}

\section{Keywords}

Nuclear Chemistry, Radiochemistry, Radiation Chemistry, Radiopharmaceutical Chemistry, Undergraduate Education, Universities

\footnotetext{
${ }^{*}$ The content of this paper was presented by the author as an invited lecture in the session of Education in Nuclear Chemistry of the 4th-INCC on 14th of September, 2014, in São Paulo, Brazil. The presentation materials can be seen by the following web link:

http://acquacon.com.br/4thincc/apresentacoes/1509/14h10_turan_unak_dia15.pdf.
} 


\section{Introduction}

An overview of the undergraduate chemistry programs of different universities across the world shows clearly that nuclear chemistry education doesn't have a permanent status in chemistry curricula like classical sub-branches of chemistry which means like organic, inorganic, analytical, physical, and biochemistry, and this verifies the existence of serious educational problems in nuclear chemistry across the world. The challenges faced by professionals in this field have been voiced at different meetings and scientific platforms and a number of works and reports were appeared [1] [2] [3] [4] [5]. In parallel of these, in this examination study, the present status of nuclear chemistry education in different universities and countries was examined and evaluated.

As it is well known, several worldwide ranking systems for universities are operated and top world universities are scored [6] [7]. Surely, these ranking and scoring lists may be discussable; but, the universities that have high ranking scores and find places in the top levels of these lists are, in general, well known, prestigious, favored and successful universities, and the universities are in competition to climb to the top levels in these lists. For the examination of the present status of nuclear chemistry education in different universities and countries, undergraduate chemistry programs of top 50 universities and the number one university in 50 different countries were carefully investigated. In addition, about 35 universities were chosen to be remarkable examples for nuclear chemistry education in different countries.

\section{The Position of Nuclear Chemistry in Chemistry Education}

Before starting the evaluation of the status of nuclear chemistry education, first of all, nuclear chemistry should be correctly defined and its place in chemistry education should be correctly determined. If it is not done, the educational problems in nuclear chemistry could not be correctly investigated and the remedies could not be correctly determined.

\section{Where Is the Place of Nuclear Chemistry in Chemistry Main Branch and What Is the Exact Definition of Nuclear Chemistry?}

As it can easily be observed from the chemistry programs of the majority of chemistry departments in different universities worldwide, the classical branches of chemistry generally consist of organic, inorganic, analytical, physical, and biochemistry subbranches as represented in Figure 1.

This reflects surely the historical development of chemistry; but, rapid development of chemical knowledge and its applications in science and technology have created too many fine subbranches in about last 50 years such as electrochemistry, polymer chemistry, medicinal chemistry, geochemistry, coordination chemistry, computational chemistry, environmental chemistry, quantum chemistry, theoretical chemistry, pharmaceutical chemistry, photochemistry, solid-state chemistry, etc. Of course, radiochemistry, radiation chemistry, radioanalytical chemistry, radiopharmaceutical chemistry, etc. should also be included in this list as other fine sub-branches of chemistry.

Here, it should be asked: "Where is the place of nuclear chemistry in the main 


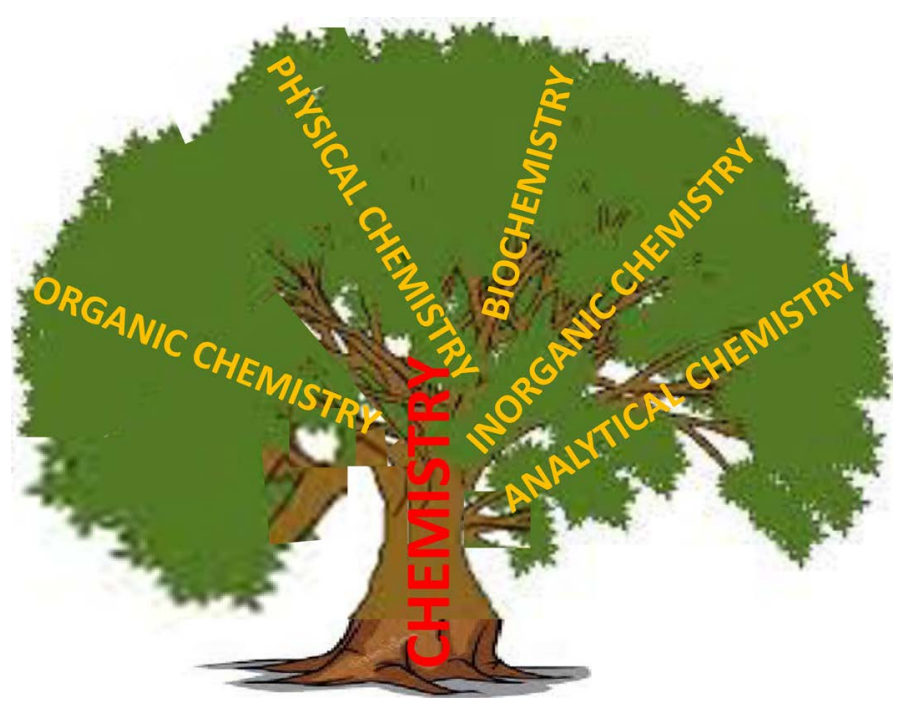

Figure 1. The chemistry branch and its classical sub-branches in natural sciences.

branch of Chemistry?" and a correct answer for this very critical question for nuclear chemistry must find. First of all, we must understand, why the main classical chemistry branches are considered to consist of five branches that is organic, inorganic, analytical, physical, and biochemistry? When basic methods and the main considerations of these sub-branches of chemistry are carefully examined, the answer to this question can easily be understood. It mean that the basic methods and the main considerations of these sub-branches of chemistry are completely different from each other; but, in spite of the appearance of new fine sub-branches that were indicated above, the main sub-branches of chemistry did not change. Why? Because, the basic methods and main considerations used by these new fine sub-branches can be collected, in principle, under these five sub-branches of chemistry.

As is well known, with the discovery of a radioactive material by Henry Becquerel in 1896 and then, some others by Marie Curie, and also nuclear radiation, chemistry envisaged using new methods and considerations for studying the chemistry of radioactive materials and related nuclear radiation. Following this discovery, the term "Radiochemistry" was introduced as the first term related to the chemistry of radioactive materials in the chemistry literature.

In the following years, according to the new applications of radioactive materials and nuclear radiation in different fields of science and technology, additional new terms were introduced into the literature of chemistry such as nuclear chemistry, radiation chemistry, radioanalytical chemistry, radiopharmaceutical chemistry, nuclear and radiochemistry, etc. Now, it should be interrogated, if all these fine sub-branches of chemistry that are related to the chemistry of radioactive materials and nuclear radiation, can be collected under the five classical sub-branches of chemistry, like all other fine sub-branches indicated above, or not? The answer is simple and clear: No! Because, all these fine sub-branches have completely different methods and considerations for studying of the chemistry related to radioactive materials and nuclear radiation than that of the five classical sub-branches of chemistry.

For this reason, all these fine sub-branches of chemistry that are related to the 
chemistry of radioactive materials and nuclear radiation should be collected under a special category and introduced into the main sub-branches of chemistry. What term can be used as an umbrella for all of these fine sub-branches of chemistry related to radioactive materials and nuclear radiation?

Looking at the famous text books published in approximately the last 60 years in this field of chemistry, which is related to the chemistry of radioactive materials and nuclear radiation and their applications in science and technology will surely help to find the term as umbrella.

In 1949 a textbook was published by Gerhard Friedlander and Joseph W. Kennedy with the title "Introduction to Radiochemistry" [8].

In 1957, another textbook in French was published by Moise Häissinsky, a French author, with the title "La Chimie Nucléaire et ses Applications", including all knowledge related to radioactive materials and nuclear radiation up that date. This book was later published in English with the title "Nuclear Chemistry and its Applications" in 1964 [9].

In 1966, Gerhard Friedlander and Joseph W. Kennedy have published the second edition of their textbook that include the name of Julian Malcolm Miller as the third author with the title "Nuclear and Radiochemistry", including similarly updated knowledge in this field [10]. Of course, this title resulted in an important question: Are nuclear chemistry and radiochemistry different fine sub-branches of chemistry? Also, does it cover other fine sub-branches such as radiation chemistry, radioanalytical chemistry, radiopharmaceutical chemistry, etc, or not? It must find correct answers to these questions.

In 1980, Gregory Choppin and Jan Rydberg published their famous textbook with the title "Nuclear Chemistry (Theory and Applications)" that included nearly all topics related to the fine sub-branches mentioned above, which are related to the chemistry of radioactive materials and nuclear radiation and their scientific and technological applications as specific chapters and/or sub-chapters [11]. It should also be noted that these authors wrote in the preface of their textbook, seemingly to obscure the confusion between the main types of this branch of chemistry that "There is no universally accepted definition for the term nuclear chemistry". At the same time, it is interesting that later editions of this textbook appeared with the title "Radiochemistry and Nuclear Chemistry" without considerably changing the contents of the main topics in the first edition [12] [13] [14].

In 2003, A handbook series consisted of five volumes published in English by Atilla Vértes, Sándor Nagy, and Zoltán Klencsár with the title "Nuclear Chemistry" and each volume specified different topics. The sixth volume was later added to this series [15].

Some other textbooks published with different titles in this period of time from the 1960 's to today are listed in Table 1. As it is seen from this table, the majority of these textbooks are titled as "Nuclear Chemistry" and a few books have "Radiochemistry" titles, while only a book has the title "Nuclear and Radiochemistry".

It is also interesting to note that a journal with the title of "Radioanalytical Chemistry" was founded in January 1968 by the famous Hungarian scientist, Tibor Braun. Surely, this was a great step for analytical chemists who work with radioactive 
Table 1. Some other textbooks published with different titles in this field of chemistry in the period of time from the 1960's to today.

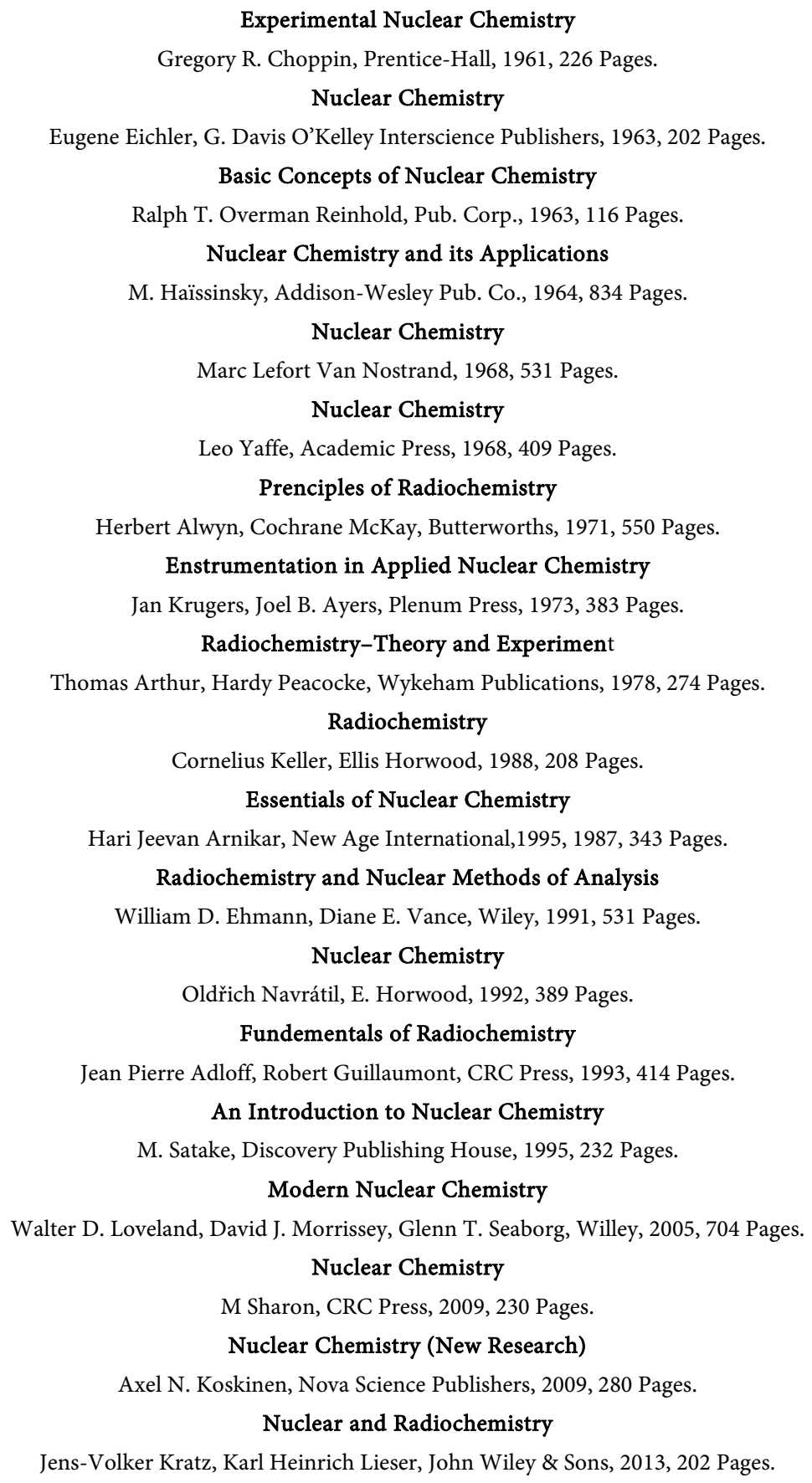

materials and nuclear radiation to obtain a good platform for publication of their research reports. According to the rapid development of this branch of chemistry, the title of that journal was updated in 1984, 16 years after the founding, to the "Journal of Radioanalytical and Nuclear Chemistry". Of course, this title has created a similar question: Are radioanalytical chemistry and nuclear chemistry different fine subbranches of chemistry, or not?

In this period of time, also new terms appeared and are used in this field of chemistry 
such as radiation chemistry, radiopharmaceutical chemistry, environmental radiochemistry, etc.

In 1999, the organizers of the International Nuclear Chemistry Forum, distributed an inquiry to many scientists who were directly or indirectly related to the chemistry of nuclear materials and nuclear radiation and their applications in which the following question was included: "Do you consider that nuclear chemistry and radiochemistry are different fields?" Out of about 250 ansvers 35\% answered Yes and 65\% answered $\mathrm{N} o$.

This story clearly verifies that a confusion of terminology or at least, turbulence exist in this branch of chemistry about the use of these terms.

Briefly, starting from the textbooks of Moise Häissinsky, the first edition of Gregory Choppin et al., the six volumes of Atilla Vértes et al., and others, nuclear chemistry should be considered as the title of the sixth main sub-branch of chemistry as is considered in the web site given as ref. [16] that covers all chemical studies related to radioactive materials and nuclear radiation including fine sub-branches such as radiochemistry, radiation chemistry, radioanalytical chemistry, radiopharmaceutical chemistry, environmental radiochemistry, and others as represented in Figure 2 and Figure 3.

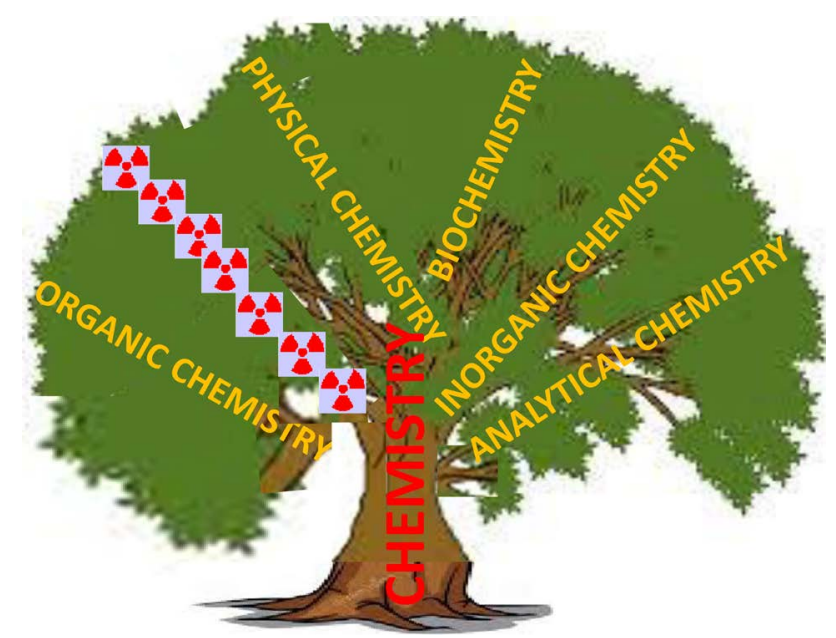

Figure 2. The place of nuclear chemistry and in the chemistry branch.

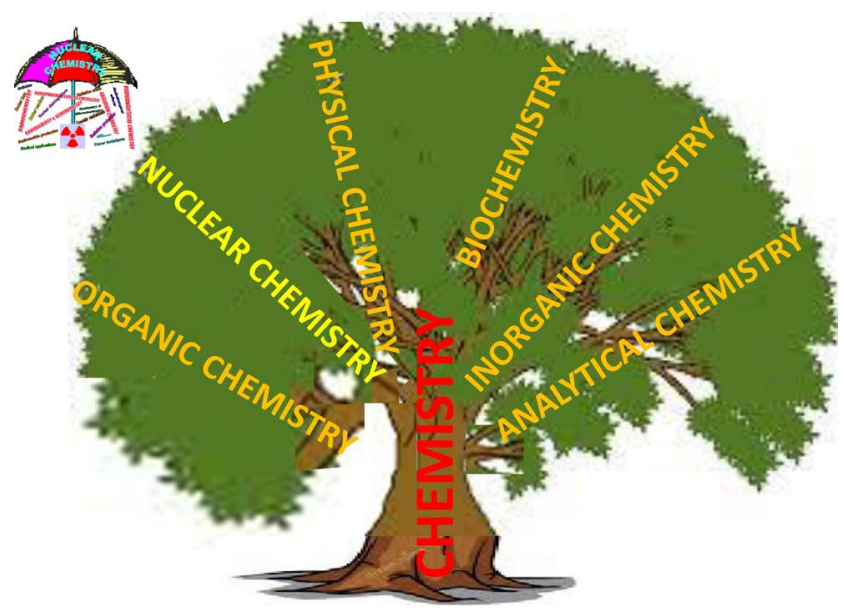

Figure 3. Nuclear chemistry its main sub-branches. 


\section{Nuclear Chemistry Education in Different Universities and Countries}

The international ranking system for universities as the success reference of universities was first considered for examination of the status of nuclear chemistry education across the world.

\subsection{Chemistry Programs of Top 50 Universities in the World}

The chemistry programs af the top 50 universities in the list of world ranking system for 2014 in the category of physical sciences were carefully browsed using their internet web addresses and their last updated undergraduate chemistry programs were examined. During this browsing, all courses with whatever title, but related to the chemistry of radioactive materials and nuclear radiation and its applications were searched.

The top 50 universities and some related courses observed are listed in Table 2. As is seen from this table, the searching result was a big disappointment for this branch of chemistry. Because only, a few universities have some courses with different titles based on nuclear phenomena or which study nuclear radiation or its applications; others have nothing! Surely, this is a very problematical situation and the reasons for this very important omission need to be very carefully evaluated.

But, it should obviously be outlined that this is only valid for chemistry programs. If not, some of these universities have several courses related to this branch of chemistry in other educational programs such as in the programs of nuclear engineering, nuclear medicine, radiopharmaceutical applications, etc. Also, universities have some courses in this field in their $\mathrm{MsD}$ and $\mathrm{PhD}$ programs.

\subsection{Chemistry Programs of No 1 Universities in 50 Different Countries}

Another examination was carried out using another criterion for universities. According to this criterion, no 1 universities in 50 different countries were considered for examination. Of course, the no 1 university of each country mean that these universities have the highest national ranking scores in their home counties. This is also another way to evaluate the universities for their successfulness.

The chemistry programs of no 1 universities in 50 different countries were also carefully browsed. Table 3 shows these no 1 universities in 50 different countries and as its seen, the general situation is not considerably different than that of the 50 top universities. Only, some universities have some courses with different titles. But still, the majority of these universities have nothing on this matter.

\subsection{Universities Having Remarkable Courses in Nuclear Chemistry}

In spite of this negative situation for education in nuclear chemistry in chemistry programs either in top 50 universities in the world or no 1 universities in 50 different countries, some universities that are far from the top of these lists and have low international or national ranking scores, do run considerably remarkable, sometimes intensive courses related to nuclear chemistry and/or its applications. As examples of these types of universities, about 35 universities were determined from different countries.

As it can be seen from the list given in Table 4, these universities have different 
Table 2. According to the universities ranking system for physical sciences, the list of top 50 universities, their countries and world scores. (This ranking list was copied from the following web site: http://www.timeshighereducation.co.uk/world-university-rankings/2013-14/subject-ranking/subject/physicalsciences).

\begin{tabular}{|c|c|c|c|c|}
\hline NO. & UNIVERSITY & COUNTRY & WORLD SCORE & COURSES \\
\hline 1 & California Institute of Technology (Caltech) & USA & 92.0 & Ge/Ch 127 Nuclear Chemistry \\
\hline 2 & Massachusetts Institute of Technology (MIT) & USA & 91.0 & \\
\hline 2 & Princeton University & USA & 91.0 & \\
\hline 4 & Harvard University & USA & 90.2 & \\
\hline 5 & University of California, Berkeley & USA & 89.9 & $\begin{array}{l}\text { CHEM } 143 \text { Nuclear Chem. } \\
\text { CHEM } 146 \text { Chemical Methods in } \\
\text { Nuclear Technology }\end{array}$ \\
\hline 5 & Stanford University & USA & 89.9 & \\
\hline 7 & University of Cambridge & UK & 88.8 & \\
\hline 8 & University of Oxford & UK & 87.3 & \\
\hline 9 & University of California, Los Angeles (UCLA) & USA & 85.1 & \\
\hline 10 & Universityof Chicago & USA & 84.9 & \\
\hline 11 & Yale University & USA & 83.6 & $\begin{array}{l}\text { CHEM 437b Chemistry of Isotopes } \\
\text { CHEM 440a Molecules and Radiation I } \\
\text { CHEM 442b Molecules and Radiation II }\end{array}$ \\
\hline 12 & ETH Zürich -Swiss Federal Institute of Technology Zürich & Switzerland & 83.2 & 535-0210-00L Radiopharma- ceutical Chemistry \\
\hline 13 & Imperial College London & UK & 82.5 & \\
\hline 14 & Columbia University & & 81.0 & \\
\hline 15 & Cornell University & USA & 80.7 & \\
\hline 16 & The University of Tokyo & Japan & 73.5 & \\
\hline 17 & Universityof Toronto & Canada & 71.7 & \\
\hline 18 & Universityof Washington & USA & 71.5 & $\begin{array}{l}\text { CHEM } 410 \text { Radiochemistry Lab. } \\
\text { CHEM } 418 \text { Nuclear Chemistry }\end{array}$ \\
\hline 19 & Ludwig-Maximilians-Universität München & Germany & 71.3 & \\
\hline 20 & Universityof California, SantaBarbara & USA & 71.1 & \\
\hline 21 & Universityof Texasat Austin & UK & 71.0 & \\
\hline 22 & University of Michigan & USA & 70.0 & \\
\hline 23 & École Polytechnique Fédérale de Lausanne & Switzerland & 69.4 & \\
\hline 24 & University of Melbourne & Australia & 68.9 & \\
\hline 25 & Université Pierre et Marie Curie & France & 67.6 & \\
\hline 26 & University of British Columbia & Canada & 67.0 & $\begin{array}{c}\text { CHEM } 417 \text { Nuclear } \\
\text { Chemistry and Radiochemistry }\end{array}$ \\
\hline 27 & University of Wisconsin-Madison & USA & 66.6 & \\
\hline 27 & Northwestern University & USA & 66.6 & \\
\hline 29 & École Normale Supérieure & France & 65.8 & \\
\hline 29 & AustralianNationalUniversity & Australia & 65.8 & \\
\hline 31 & Georg-August-UniversitätGöttingen & Germany & 65.5 & \\
\hline
\end{tabular}




\section{Continued}

\begin{tabular}{|c|c|c|c|c|}
\hline 32 & Peking University & China & 65.3 & Radiochemistry Radiation chemistry \\
\hline 33 & University of Illinois at Urbana Champaign & USA & 65.0 & \\
\hline 34 & Rice University & Australia & 64.7 & \\
\hline 35 & Brown University & Canada & 64.6 & \\
\hline 36 & Kyoto University & Japan & 64.3 & \\
\hline 37 & University of Edinburgh & UK & 61.6 & \\
\hline 38 & Pennsylvania State University & USA & 61.5 & \\
\hline 38 & École Polytechnique & France & 61.5 & \\
\hline 40 & Carnegie Mellon University & USA & 61.4 & \\
\hline 41 & National University of Singapore (NUS) & Singapore & 61.2 & \\
\hline 42 & Technische Universität München & Germany & 61.0 & Radiochemistry \\
\hline 43 & Universität Heidelberg & Germany & 60.5 & \\
\hline 44 & University of Colorado Boulder & USA & 59.9 & \\
\hline 45 & University of California, San Diego & USA & 59.6 & \\
\hline 47 & Georgia Institute of Technology (Georgia Tech) & USA & 59.4 & \\
\hline 48 & Stockholm University & Sweden & 58.1 & \\
\hline 49 & University of Minnesota & USA & 58.0 & \\
\hline 50 & Universityof Manchester & UK & 57.9 & \\
\hline
\end{tabular}

Table 3. The list of no 1 universities in 50 different countries, their world scores and related courses. (The list of No.1 universities in different countries was copied from the following web site: http://www.topuniversities.com).

\begin{tabular}{ccccc}
\hline NO. & UNIVERSITY & COUNTRY & WORLD ORDER & COURSES \\
\hline 1 & Massachusetts Institute of Technology (MIT) & USA & 5 th \\
2 & University of Cambridge & UK & 7 th \\
3 & ETH Zurich (Swiss Federal Institute of & Switzerland & 14 th \\
4 & Technology) & Singapore & 26 th \\
5 & National University of Singapore (NUS) & Canada & 35 th \\
6 & The Hong Kong University of Science and Techn. & Hong Kong & 43 th \\
7 & Seoul National University & South Korea & 44 th \\
8 & Peking University & China & 45 th \\
9 & Australian National University & Australia & 48 th \\
10 & KU Leuven & Belgium & 61 th \\
11 & Ecole Normale Supérieure, Paris & France & 65 th \\
12 & Technische Universität München & Germany & 87 th \\
13 & University of Helsinki & Finland & 100 th \\
14 & Lund University & Sweden & 123 rd \\
\hline
\end{tabular}




\section{Continued}

\begin{tabular}{|c|c|c|c|c|}
\hline 15 & University of Cape Town & South Africa & 126 th & \\
\hline 16 & National Taiwan University (NTU) & Taiwan & $142 \mathrm{nd}$ & \\
\hline 17 & University of Amsterdam & Netherland & 144 th & \\
\hline 18 & University of Copenhagen & Denmark & 150th & \\
\hline 19 & University of Vienna & Austria & 170 th & \\
\hline 20 & University of Oslo & Norway & 185 th & \\
\hline 21 & Hebrew University of Jerusalem & Israel & 191th & \\
\hline 22 & Universidad de Buenos Aires & Argentina & $>200$ th & \\
\hline 23 & Universidade de São Paulo (USP) & Brazil & $>200$ th & \\
\hline 24 & Pontificia Universidad Católica de Chile & Chile & $>200$ th & \\
\hline 25 & Universidad de Los Andes Colombia & Colombia & $>200$ th & \\
\hline 26 & Charles University & Czech Republic & $>200$ th & \\
\hline 27 & American University in Cairo & Egypt & $>200$ th & \\
\hline 28 & Aristotle University of Thessaloniki & Greece & $>200$ th & \\
\hline 29 & Indian Institute of Technology Delhi (IITD) & India & $>200$ th & \\
\hline 30 & University of Indonesia & Indonesia & $>200$ th & \\
\hline 31 & Trinity College Dublin & Ireland & $>200$ th & Nuclear and Medicinal Inorganic Chemistry \\
\hline 32 & University of Bologna & Italy & $>200$ th & \\
\hline 33 & The University of Tokyo & Japan & $>200$ th & \\
\hline 34 & L.N. Gumilyov Eurasian National University & Kazakhstan & $>200$ th & \\
\hline 35 & American University of Beirut (AUB) & Lebanon & $>200$ th & \\
\hline 36 & Universiti Malaya (UM) & Malaysia & $>200$ th & \\
\hline 37 & $\begin{array}{l}\text { Universidad Nacional Autónoma de México } \\
\text { (UNAM) }\end{array}$ & Mexico & $>200$ th & \\
\hline 38 & The University of Auckland & New Zeland & $>200$ th & \\
\hline 39 & Sultan Qaboos University & Oman & $>200$ th & \\
\hline 40 & $\begin{array}{l}\text { National University of Sciences and Technology } \\
\text { (NUST) Islamabad }\end{array}$ & Pakistan & $>200$ th & \\
\hline 41 & University of the Philippines & Philippines & $>200$ th & $\begin{array}{l}\text { Radioisotope Tech. (in Analy. Chem.), Nuclear } \\
\text { Chemistry (in Inorganic Chem.) }\end{array}$ \\
\hline 42 & Jagiellonian University & Poland & $>200$ th & \\
\hline 43 & University of Coimbra & Portugal & $>200$ th & \\
\hline 44 & Lomonosov Moscow State University & Russia & $>200$ th & Department of Radiochemistry \\
\hline 45 & King Saud University & Saudi Arabia & $>200$ th & \\
\hline 46 & Universitat Autónoma de Barcelona & Spain & $>200$ th & \\
\hline 47 & Chulalongkorn University & Thailand & $>200$ th & \\
\hline 48 & Bilkent University & Turkey & $>200$ th & \\
\hline 49 & United Arab Emirates University & $\begin{array}{l}\text { United Arab } \\
\text { Emirate }\end{array}$ & $>200$ th & \\
\hline 50 & Universidad ORT Uruguay & Uruguay & $>200$ th & \\
\hline
\end{tabular}


Table 4. List of universities that are far from the top of the lists given in Table 1 and Table 2 and have low international or national ranking scores, do run considerably remarkable, sometimes intensive courses related to nuclear chemistry and/or its applications, as examples of these types of universities.

\begin{tabular}{|c|c|c|c|}
\hline UNIVERSITY & COUNTRY & $\begin{array}{l}\text { WORLD ORDER \& } \\
\text { RANKING SCORE }\end{array}$ & COURSES \\
\hline University of Kentucky & & & CHE 520: Radiochemistry \\
\hline $\begin{array}{l}\text { College of Arts and Sciences } \\
\text { Department of Chemistry }\end{array}$ & USA & $>400$ th & $\begin{array}{l}\text { CHE 521: Radiochemistry Lab. } \\
\text { CHE 616: Nuclear Chemistry }\end{array}$ \\
\hline $\begin{array}{l}\text { Tennessee Tech. University } \\
\text { Department of Chemistry }\end{array}$ & USA & $>400$ th & $\begin{array}{l}\text { CHEM 4310/5310 } \\
\text { Nuclear and Radiochemistry }\end{array}$ \\
\hline $\begin{array}{c}\text { Missouri University College of Arts and Science } \\
\text { Department of Chemistry }\end{array}$ & USA & $>400$ th & $\begin{array}{l}\text { National Nuclear Chemistry } \\
\text { Summer Schools }\end{array}$ \\
\hline $\begin{array}{l}\text { Delft University of Technology } \\
\text { Faculty of Applied Sciences }\end{array}$ & Netherland & $\begin{array}{c}\text { 69th } \\
(59.1)\end{array}$ & CH3771: Nuclear Chemistry \\
\hline $\begin{array}{l}\text { Universty of Maryland } \\
\text { Department of Chemistry \& Biochemistry }\end{array}$ & USA & $>400$ th & CHEM705: Nuclear Chemistry \\
\hline Defance Academy of the United Kingdom & UK & & $\begin{array}{l}\text { (NCC) - ME844N } \\
\text { Nuclear Chemistry }\end{array}$ \\
\hline $\begin{array}{l}\text { Indiana University } \\
\text { Department of Chemistry }\end{array}$ & USA & $\begin{array}{l}132 \mathrm{nd} \\
(50.1)\end{array}$ & C460: Nuclear Chemistry \\
\hline $\begin{array}{c}\text { Berkley } \\
\text { University of California }\end{array}$ & USA & $>400$ th & $\begin{array}{c}\text { CHEM 143: Nuclear Chemistry } \\
\text { CHEM 243: Advanced Nuclear Structure and Reactions }\end{array}$ \\
\hline University of Nord Carolina & USA & $>400$ th & $\begin{array}{l}073 \text { First-Year Seminar: The Broad Scope of Nuclear Chemistry } \\
\text { (From Atomic Bombs to Cancer Treatments) }\end{array}$ \\
\hline KTH Royal Institute of Technology & Sweden & $\begin{array}{l}117 \text { th } \\
(51.6)\end{array}$ & KD2080: Nuclear Chemistry \\
\hline $\begin{array}{l}\text { Michigan State University } \\
\text { Department of Chemistry }\end{array}$ & USA & $\begin{array}{c}83 \mathrm{rd} \\
(55.9)\end{array}$ & $\begin{array}{l}\text { CEM 485: Modern Nuclear Chemistry } \\
\text { CEM 985: Selected Topics in Nuclear Chemistry }\end{array}$ \\
\hline $\begin{array}{l}\text { Manchester University } \\
\text { School of Chemistry }\end{array}$ & UK & $>400$ th & CHEM40311: Radiochemistry and Nuclear Chemistry \\
\hline Chalmers Institute of Technology & Sweden & $>400$ th & Nuclear Chemistry \\
\hline $\begin{array}{l}\text { Jomo Kenyatta University of Agriculture and } \\
\text { Technology }\end{array}$ & Kenya & $>400$ th & SCH 2203: Nuclear Chemistry and Radiochemistry \\
\hline $\begin{array}{l}\text { Mount Royal University } \\
\text { Fac. of Science \& Tech. } \\
\text { Department of Chemistry }\end{array}$ & Canada & $>400$ th & CHEM 3801: Nuclear Chemistry \\
\hline $\begin{array}{l}\text { University of British Colombia } \\
\text { Faculty of Science Department of Chemistry }\end{array}$ & Canada & $>400$ th & Nuclear and Radiochemistry \\
\hline $\begin{array}{l}\text { Rockhurst University } \\
\text { Department of Chemistry }\end{array}$ & USA & $>400$ th & CH 3650: Nuclear Chemistry \\
\hline $\begin{array}{l}\text { University of Bergen } \\
\text { Department of Chemistry }\end{array}$ & Norway & 201 th -225 th & KJEM260: Radiochemistry and Radioactivity \\
\hline $\begin{array}{l}\text { University of Massachusetts Lowell } \\
\text { Department of Chemistry }\end{array}$ & USA & $>400$ th & 95.441: Radiochemistry \\
\hline $\begin{array}{l}\text { University of Kentucky } \\
\text { Department of Chemistry }\end{array}$ & USA & $>400$ th & $\begin{array}{l}\text { CHE 520: Radiochemistry } \\
\text { CHE 521: Radiochemistry Lab. } \\
\text { CHE 616: Nuclear Chemistry }\end{array}$ \\
\hline $\begin{array}{l}\text { Uppsala Universirty } \\
\text { Department of Chemistry }\end{array}$ & Sweden & $>400$ th & UU-49001: Nuclide Production and Radiochemistry \\
\hline
\end{tabular}




\section{Continued}

\begin{tabular}{|c|c|c|c|}
\hline Norvegian University of Life Scences & Norway & $>400$ th & KJM350 Radiation and Radiochemistry \\
\hline $\begin{array}{c}\text { University of Utah } \\
\text { Department of Chemistry }\end{array}$ & USA & $\begin{array}{l}143 r d \\
(49.1)\end{array}$ & 3200: Radiochemistry I \\
\hline $\begin{array}{l}\text { Washington University in St. Louis } \\
\text { Department of Chemistry }\end{array}$ & USA & $>400$ & Chemistry 536: Radiochemistry for the Life Sciences \\
\hline $\begin{array}{l}\text { Delft University of Technology } \\
\text { Fac. Appl. Sciences }\end{array}$ & $\begin{array}{l}\text { Nether- } \\
\text { land }\end{array}$ & $\begin{array}{l}69 \text { th } \\
(59.1)\end{array}$ & CH3771: Nuclear Chemistry \\
\hline $\begin{array}{l}\text { California State University Northridge } \\
\text { Dept.of Chem.\& Biochem. }\end{array}$ & USA & $>400$ th & Chem 481: Radiochemistry \\
\hline $\begin{array}{c}\text { James Madson University } \\
\text { Department of Chemistry \& Biochemistry }\end{array}$ & USA & $>400$ th & $\begin{array}{l}\text { CHEM 450: Nuclear and Radiation Chemistry } \\
\text { CHEM 450L: Laboratory for Nuclear and Radiation Chemistry }\end{array}$ \\
\hline $\begin{array}{l}\text { University of Oslo } \\
\text { Department of Chemistry }\end{array}$ & Norway & $\begin{array}{l}185 \text { th } \\
(43.3)\end{array}$ & $\begin{array}{l}\text { FYS-KJM4710: Radiation and Radiation Dosimetry } \\
\text { KJM5901: Radiochemical Methods } \\
\text { KJM5950:Radiopharmaceutical Chemistry }\end{array}$ \\
\hline $\begin{array}{c}\text { University of Nairobi } \\
\text { Department of Chemistry }\end{array}$ & Kenya & $>400$ th & SCH 408: Nuclear and Radiation Chemistry \\
\hline Western University & Canada & $\begin{array}{l}\text { 22nd } \\
(77.1)\end{array}$ & Chem 4404: Radiation and Nuclear Systems Chemistry \\
\hline $\begin{array}{l}\text { University of Washington } \\
\text { Depatment of Chemistry }\end{array}$ & USA & $\begin{array}{l}25 \text { th } \\
(73.4)\end{array}$ & $\begin{array}{c}\text { Chemistry 418: Nuclear Chemistry and Radiochemistry } \\
\text { Chemistry 410: Nuclear Chemistry Laboratory }\end{array}$ \\
\hline Western University Department of Chemistrty & Canada & $>400$ th & Chem 4404: Radiation and Nuclear Systems Chemistry \\
\hline Royal Institute of Technology & Sweden & $>400$ th & Nuclear Chemistry \\
\hline $\begin{array}{l}\text { University of Texas } \\
\text { Chemistry Program }\end{array}$ & USA & $\begin{array}{l}188 \text { th } \\
(45.2)\end{array}$ & CHEM 4389: Modern Nuclear Chemistry \\
\hline $\begin{array}{l}\text { St. Kliment Ohridsky University of Sofia } \\
\text { Nuclear Chemistry } \\
\text { BS Degree Program }\end{array}$ & Bulgaria & $>400$ th & GOOD EXAMPLE \\
\hline $\begin{array}{l}\text { Czech Technical University } \\
\text { Department of Nuclear Chemistrty }\end{array}$ & Czech Rep. & $>400$ th & GOOD EXAMPLE \\
\hline
\end{tabular}

courses under different titles; but, the majority of the course titles are nuclear chemistry. Of course, this is a good statement for nuclear chemistry education. In this list you see two universities that were noted as "Good example" at the last lines of the Table 3. In case of establishing a nuclear chemistry ranking system for universities, these two universities should be recognized as the top universities in the world according to the nuclear chemistry ranking system. One of these two universities is Czech Technical University in the Czech Republic has a Department of Nuclear Chemistry which means that nuclear chemistry is as a basic field of education, offering many courses related to this field as shown in Table 5.

Another good example is the Faculty of Chemistry in St. Kliment Ohridsky University of Sofia in Bulgaria. This faculty has a Bachelor Degree program for nuclear chemistry, which includes many courses related to this field as shown in Table 6.

The details of an undergraduate nuclear chemistry program at the Department of Chemistry, Ege University, Faculty of Science, in Turkey was published in 2009 with the title "An ideal teaching program of nuclear chemistry in the undergraduate chemistry curriculum". Surely, this was also a good example for education in nuclear 
Table 5. Czech Technical University Department of Nuclear Chemistry, as one of good examples for education in nuclear chemistry (This information is copied from the following web site: http://www.jaderna-chemie.cz/?predmet=prehled_en).

CZECH TECHNICAL UNIVERSITY DEPARTMENT OF NUCLEAR CHEMISTRTY Courses provided by this Department:

Analytical Calculations and Chemometry Principals

Aplication of Radionuclides I

Aplication of Radionuclides II

Application of Radiation Methods

Bachelor's thesis I

Bachelor's thesis II

Compile a Search I

Compile a Search II

Determination of Radionuclides in the Environment

Environmental Chemistry and Radioecology

Excursion I

Excursion II

General Chemistry

General Chemistry I

General Chemistry II

General Chemistry Calculations

Chemistry of Radioactive Elements

Instrumental Methods I

Instrumental Methods II

Introduction to Nuclear Chemistry

Introduction to Photochemistry and Photobiology

Ionising Radiation Detection

Laboratory Practice in the Instrumental Methods

Master's Thesis I

Master's Thesis II

Measurement and Data Handling

Modelling of the Migration Processes in the Environment

Nuclear chemistry I

Nuclear chemistry II

Nuclear Materials Technology

Nuclear Power Plants Design and Operation

Numerical Simulation of Complex Environmental Processes

$$
\begin{aligned}
& \text { Physical Chemistry } 1 \\
& \text { Physical Chemistry } 2 \\
& \text { Physical Chemistry } 3 \\
& \text { Physical Chemistry } 4 \\
& \text { Physical Chemistry } 5
\end{aligned}
$$

Practical Exercises in Radiation Methods in Biology and Medicine

Practical Exercises in Radiation Chemistry 


\title{
Continued
}

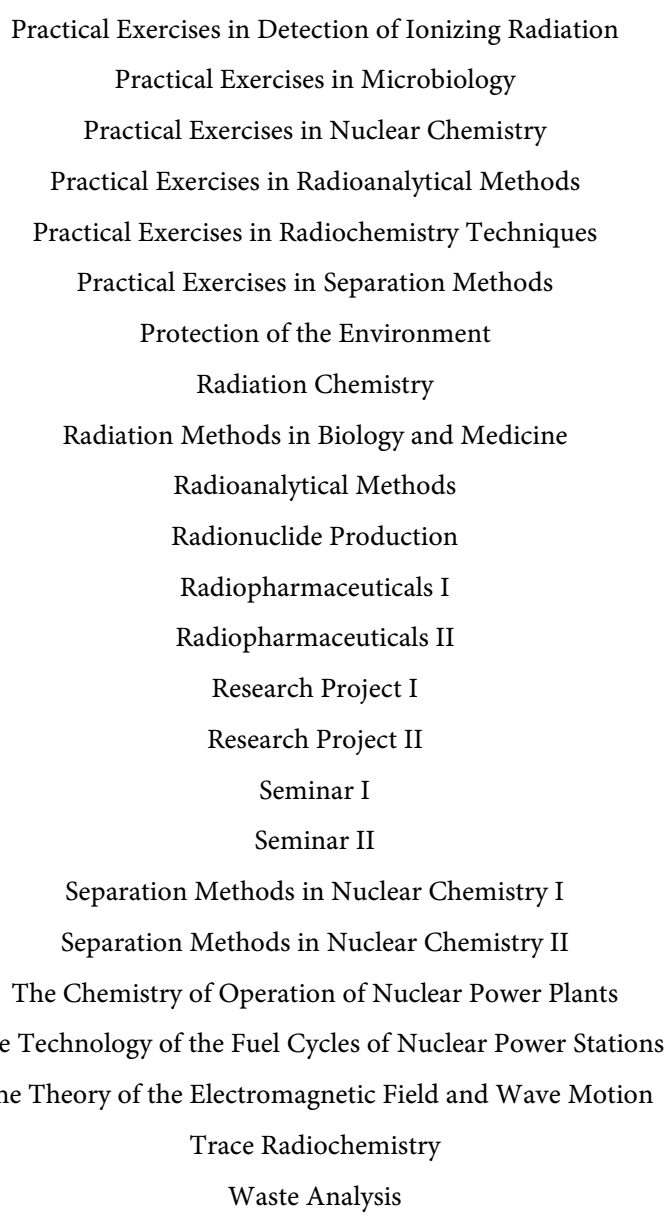

Waste Management and Treatment

Table 6. St. Kliment Ohridsky University of Sofia in Bulgaria Nuclear Chemistry Bachelor Degree Program in the Faculty of Chemistry as one of good examples for education in nuclear chemistry. (This information is copied from the following web site: http://www.chem.uni-sofia.bg/BachNuclChem_en.htm).

\section{ST. KLIMENT OHRIDSKY UNIVERSITY OF SOFIA IN BULGARY FACULTY OF CHEMISTRY}

\section{Nuclear Chemistry Bachelor Degree Program}

Related courses provided by this program:

\author{
Nuclear and Radiochemistry I \\ Nuclear and Radiochemistry II \\ Radiation Protection \\ Radioanalitycal Chemistry
}

Chemistry of the Nuclear Fuel Cycle and of Nuclear Reactions

Production of Radioactive Isotopes and Labeled Compounds

Radioactive Wastes

Nuclear safety, Risk Analysis and Risk Informed Decision Making

Fundamental of Radiobiology 
chemistry [17].

\section{Conclusions}

This short overview of nuclear chemistry education programs has reached some important conclusions:

1) The umbrella role of nuclear chemistry should be strongly supported everywhere;

2) Nuclear chemistry should be emphasized as the sixth main sub-branch of chemistry;

3) The overview of nuclear chemistry education in universities across the world has clearly indicated that nuclear chemistry education has not yet achieved a classical status in chemistry curricula worldwide like organic, analytical, inorganic, physical, and biochemistry; but, all undergraduate chemistry programs of universities across the world should cover at least one nuclear chemistry course with some laboratory experiments, like in the case of other main sub-branches of chemistry;

4) It is evident that the majority of active chemistry staff surely does not have enough knowledge of today's importance of nuclear chemistry and its scientific and technological applications, which results in a huge lack of nuclear chemistry education in the formulation of chemistry curricula;

5) This present status prevents the education of new staffs in nuclear chemistry and so, this creates a vicious circle for the subject;

6) The universities having remarkable nuclear chemistry courses which were identified can be attributed to the personal efforts of some well-educated staff in nuclear chemistry and this does not guarantee that the same status will continue in the future in their universities after their retirements and for this reason, it will be evident that as notified by Gregory Choppin "The need for radiochemists (he meant surely nuclear chemists) must grow; but in most countries, including the US, there will soon be no professors to train them!";

7) Today's active nuclear chemistry staff should understand that they have been charged with a very important mission for the future status of nuclear chemistry and that they need to be much more active and try to help other chemistry staff in their universities to understand that nuclear chemistry education should have a permanent place in chemistry curricula without depending on temporary personnel efforts and activities;

8) Nuclear chemistry staff should communicate with all national or international scientific organizations to spread more understanding of the important role of nuclear chemistry in scientific and technological applications required for future human life;

9) The number of civil national and international organizations such as the International Nuclear Chemistry Socciety (INCS) and the Radiochemistry Society in the US, etc. should be increased;

10)A master program for nuclear chemistry in undergraduate education needs to be formulated and it should be recommended for introduction into all chemistry curricula in various universities across the world. This would help to create more interest in the field of nuclear chemistry among the younger generation. 


\section{References}

[1] Rössbach, M. (2002) Assessment of the Teaching and Applications in Radiochemistry. IAEA Report of a Technical Meeting, 10-14 June, Antalya, Turkey.

[2] Ünak, T. (2005) Round Table Discussion Panel Report. 1st-INCC, 22-29 May, Kusadasi, Turkey.

[3] (2010) European Commission, Seventh Framework Programme, Contract Number: FP7CA249690, Cooperation in Education in Nuclear Chemistry (CINCH).

[4] Adloff, J.P. (1990) Information on Training in Radiochemistry and Nuclear Techniques. Pure and Applied Chemistry, 62, 959-1002.

[5] Education in Nuclear Science, A Status Report and Recommendations for the Beginning of the 21st Century, A Report of the DOE/NSF Nuclear Science Advisory Committee Subcommittee on Education, November 2004.

[6] http://www.timeshighereducation.co.uk/world-university-rankings/2013-14/world-ranking

[7] http://www.topuniversities.com

[8] Friedlander, G. and Kennedy, J.W. (1949) Introduction to Radiochemistry. John Wiley \& Sons Inc., New York.

[9] Häissinsky, M. (1957) La Chimie Nucléaire et ses Applications, Masson et Cie.

[10] Häissinsky, M. (1964) Nuclear Chemistry and İts Applications. Addison-Wesley Publishing Co., Paris.

[11] Friedlander, G., Kennedy, J.W. and Miller, J.M. (1966) Nuclear and Radiochemistry. John Wiley \& Sons Inc., New York.

[12] Choppin, G. and Rydberg, J. (1980) Nuclear Chemistry (Theory and Applications). Pergamon Press, Oxford.

[13] Choppin, G., Liljenzin, J.O. and Rydberg, J. (1995) Radiochemistry and Nuclear Chemistry. 2nd Edition, Butterworth-Heinnemann Ltd., Oxford.

[14] Choppin, G., Liljenzin, J.O., Rydberg, J. and Ekberg, C. (2012) Radiochemistry and Nuclear Chemistry. 4th Edition, Academic Press, Oxford.

[15] Vértes, A., Nagy, S. and Klencsár, Z. (2003) Nuclear Chemistry: Vol. 1: Basics of Nuclear Science; Vol. 2: Elements and Isotopes; Vol. 3: Chemical Applications of Nuclear Reactions and Radiations; Vol. 4: Radiochemistry and Radiopharmaceutical Chemistry in Life Sciences; Vol. 5: Instrumentation, Separation Techniques, Environmental Issues; Vol. 6: Nuclear Energy Production and Safety Issues; Kluger Academic Publishers.

[16] http://www.buzzle.com/articles/different-branches-of-chemistry.html

[17] Ünak, T. (2009) An Ideal Teaching Program of Nuclear Chemistry in the Undergraduate Chemistry Curriculum. Journal of Radioanalytical and Nuclear Chemistry, 280, 223-226. 
Submit or recommend next manuscript to SCIRP and we will provide best service for you:

Accepting pre-submission inquiries through Email, Facebook, LinkedIn, Twitter, etc. A wide selection of journals (inclusive of 9 subjects, more than 200 journals)

Providing 24-hour high-quality service

User-friendly online submission system

Fair and swift peer-review system

Efficient typesetting and proofreading procedure

Display of the result of downloads and visits, as well as the number of cited articles Maximum dissemination of your research work

Submit your manuscript at: http://papersubmission.scirp.org/

Or contact aces@scirp.org 